\title{
Heat-Shock Protein 70 (Hsp70) Expression in Four Limpets of the Genus Lottia: Interspecific Variation in Constitutive and Inducible Synthesis Correlates With in situ Exposure to Heat Stress
}

\author{
YUNWEI DONG ${ }^{1,2}$, LUKE P. MILLER ${ }^{1}$, JON G. SANDERS ${ }^{1}$, AND GEORGE N. SOMERO ${ }^{1, *}$ \\ ${ }^{1}$ Hopkins Marine Station, Stanford University, Pacific Grove, California 93950-3094; and ${ }^{2}$ The Key \\ Laboratory of Mariculture, Ministry of Education, Fisheries College, Ocean University of China, \\ Qingdao, People's Republic of China 266003
}

\begin{abstract}
Limpets of the genus Lottia occupy a broad vertical distribution on wave-exposed rocky shores, a range that encompasses gradients in the frequency and severity of thermal and desiccation stress brought on by aerial emersion. Using western blot analysis of levels of heat-shock protein 70 (Hsp70), we examined the heat-shock responses of four Lottia congeners: Lottia scabra and L. austrodigitalis, which occur in the high-intertidal zone, and L. pelta and $L$. scutum, which are restricted to the low- and midintertidal zones. Our results suggest distinct strategies of Hsp70 expression in limpets occupying different heights and orientations in the rocky intertidal zone. In freshly field-collected animals and in specimens acclimated at ambient temperature $\left(\approx 14{ }^{\circ} \mathrm{C}\right)$ for 14 days, the two highintertidal species had higher constitutive levels of Hsp70 than the low- and mid-intertidal species. During aerial exposure to high temperatures, the two low-shore species and L. austrodigitalis exhibited an onset of Hsp70 expression at $28^{\circ} \mathrm{C}$; no induction of $\mathrm{Hsp} 70$ occurred in L. scabra. Our findings suggest that high-intertidal congeners of Lottia employ a "preparative defense" strategy involving maintenance of high constitutive levels of Hsp70 in their cells as a mechanism for protection against periods of extreme and unpredictable heat stress.
\end{abstract}

Received 28 March 2008; accepted 24 June 2008.

* To whom correspondence should be addressed. E-mail: somero@ stanford.edu

\section{Introduction}

The rocky intertidal zone is among the most physically harsh environments on earth (Tomanek and Helmuth, 2002). In this habitat, environmental conditions range from fully aquatic to fully terrestrial over vertical distances of a few meters or less. Temperature and desiccation potential change seasonally and daily, depending on the tidal cycle and ambient weather conditions (Helmuth, 2002). During low tide, thermal stress and desiccation due to aerial emersion can affect growth, survival, and reproduction significantly (Blanchette et al., 2007). The terrestrial conditions present at low tide thus can play an important role in determining the zonation patterns of intertidal animals (Hochachka and Somero, 2002; Somero, 2002; Tomanek and Somero, 2002; Denny and Harley, 2006; Denny et al., 2006; Helmuth et al., 2006).

Because the energy costs of cumulative sublethal thermal stress may play important roles in determining range boundaries, it is critical to elucidate the mechanisms contributing to these costs. Proteins have been a focal point of such analyses because their structures are thermally labile and show consistent temperature-related adaptive variation (Somero, 1995). A fine balance between stability and lability is a consistent feature of protein evolution, and the thermal stabilities of orthologous homologs almost invariably are positively correlated with adaptation temperatures (Somero, 1995). When thermal stress is encountered, the fine balance between stability and lability in proteins is broken, and some proteins lose their higher-order structures and related functions. As a consequence of protein denaturation, the synthesis of heat-shock proteins (Hsps) is initiated 
to promote refolding of denatured proteins and prevent further protein unfolding and aggregation (Morimoto and Santoro, 1998; Feder and Hofmann, 1999). The biosynthesis and chaperoning activities of Hsps are energetically costly, suggesting a tradeoff between thermal tolerance and use of metabolic energy for growth and reproduction (Somero, 2002). Thus, it is commonly found that expression of inducible paralogs of Hsps occurs only above a certain threshold induction temperature (Sanders et al., 1991; Hofmann and Somero, 1996; Feder and Hofmann, 1999; Tomanek and Somero, 2000). In intertidal snails of the genus Tegula (now Chlorostoma), threshold induction temperature is correlated with vertical and biogeographic zonation, such that more cold-adapted species initiate Hsp expression at lower temperatures than warm-adapted congeners when exposed to heat stress in controlled laboratory conditions (Tomanek and Somero, 1999). However, little is known about the relationship between the vertical position of a species and the level of constitutive expression of heatshock proteins in the absence of thermal stress.

To examine this relationship, we studied four congeners of limpets belonging to the genus Lottia that have different vertical distributions. Limpets are common on rocky shores throughout the world from the tropics to polar regions, and they play important roles in intertidal marine ecosystems (Castenholz, 1961; Dayton, 1971; Branch and Newell, 1978; Davies et al., 2007; Nakano and Ozawa, 2007). Extensive research has been carried out on the phylogeography (Nakano and Ozawa, 2007), habitat partitioning (Shotwell, 1950; Haven, 1970), and thermal tolerance of limpets (Wolcott, 1973; Collins, 1977; Roland and Ring, 1977). Recently, the limpet Lottia gigantea has been used to create a heat-budget model for predicting body temperatures in the field (Denny et al., 2006). Though many studies have been carried out on the heat-shock responses of intertidal animals to high temperatures (Roberts et al., 1997; Tomanek and Somero, 1999; Tomanek and Helmuth, 2002; Berger and Emlet, 2007), few of them have focused on intertidal limpets (Sanders et al., 1991).

Limpets in the genus Lottia on the coast of California provide an opportunity to examine differences in stress tolerance among a group of closely related species that span the low- to the high-intertidal zones and represent a gradient in potential exposure to high temperature and desiccation stress. To investigate the heat-shock response of limpets inhabiting different intertidal zones, the levels of Hsp70 were measured in freshly field-collected specimens, in animals held in the laboratory under conditions that were not thermally stressful (ambient seawater temperatures) for 2 weeks to gauge constitutive levels of Hsp70 expression, and in individuals exposed to two types of aerial emersion meant to mimic realistic stress events in the field, as described by Denny et al. (2006).

The field and laboratory experiments described below test the hypothesis that congeners living higher on the shore maintain higher constitutive levels of $\mathrm{Hsp} 70$ and are able to mount a stronger heat-shock response, appropriate for the greater frequency and severity of thermal stress events they are likely to experience in their preferred habitat, relative to species from the mid- to low-intertidal zones.

\section{Materials and Methods}

\section{Distribution, collection, and maintenance of animals}

Four limpet species, Lottia scabra Gould, L. austrodigitalis Murphy, L. pelta Rathke, and L. scutum Rathke were sampled in different intertidal zones as shown in Figure 1. L. scabra and $L$. austrodigitalis inhabit the high-intertidal zone, while $L$. pelta and $L$. scutum are restricted to the lowand mid-intertidal zones. In the high-intertidal zone, $L$. scabra typically occupies horizontal surfaces fully exposed to the sun; $L$. austrodigitalis primarily occupies vertical or overhanging surfaces (Shotwell, 1950; Haven, 1970; Wolcott, 1973).

L. austrodigitalis is the sibling species of $L$. digitalis, and the two species, which are difficult to distinguish on the basis of visually observable traits, have parapatric distributions that overlap in central California (Murphy, 1978; Crummett and Eernisse, 2007). Therefore, a genetic method was used to distinguish $L$. austrodigitalis and $L$. digitalis (Stephen Palumbi, Hopkins Marine Station, Stanford University; pers. comm.). Partial sequences of $16 \mathrm{~S}$ mtDNA were amplified using specific primers $16 \mathrm{sAr}$ and $16 \mathrm{sBr}$ (Palumbi, 1996). The products were digested with the restriction enzyme Hae II. L. digitalis yields only the original uncut band (690 bp), and L. austrodigitalis yields two bands (171 and $520 \mathrm{bp}$ ). Among 191 individuals that we sampled around Hopkins Marine Station (HMS), Pacific Grove, California $\left(36^{\circ} 36^{\prime} \mathrm{N}, 121^{\circ} 54^{\prime} \mathrm{W}\right), 12 \%$ of individuals were $L$. digitalis and $88 \%$ were $L$. austrodigitalis.

Specimens of $L$. scabra were sampled on 8 August 2007 and specimens of the other three species were sampled on 17 August 2007 at HMS. After collection on a falling high tide, 10 individuals of each species were immediately frozen with liquid nitrogen and stored at $-70{ }^{\circ} \mathrm{C}$ for use as "field" samples. About 100 individuals of each species were acclimated at $14-17{ }^{\circ} \mathrm{C}$. During acclimation, limpets were immersed twice daily in ambient seawater $\left(\approx 14{ }^{\circ} \mathrm{C}\right)$ for $6 \mathrm{~h}$ to simulate the natural high tide. Air temperatures during acclimation were about $14-17{ }^{\circ} \mathrm{C}$, and conditions in the holding tank remained moist and cool even during the simulated low tide so that desiccation and temperature stress would be minimal. After acclimation for 14 days, individuals from all four species were sampled and frozen at $-70{ }^{\circ} \mathrm{C}$ as "control" specimens. 


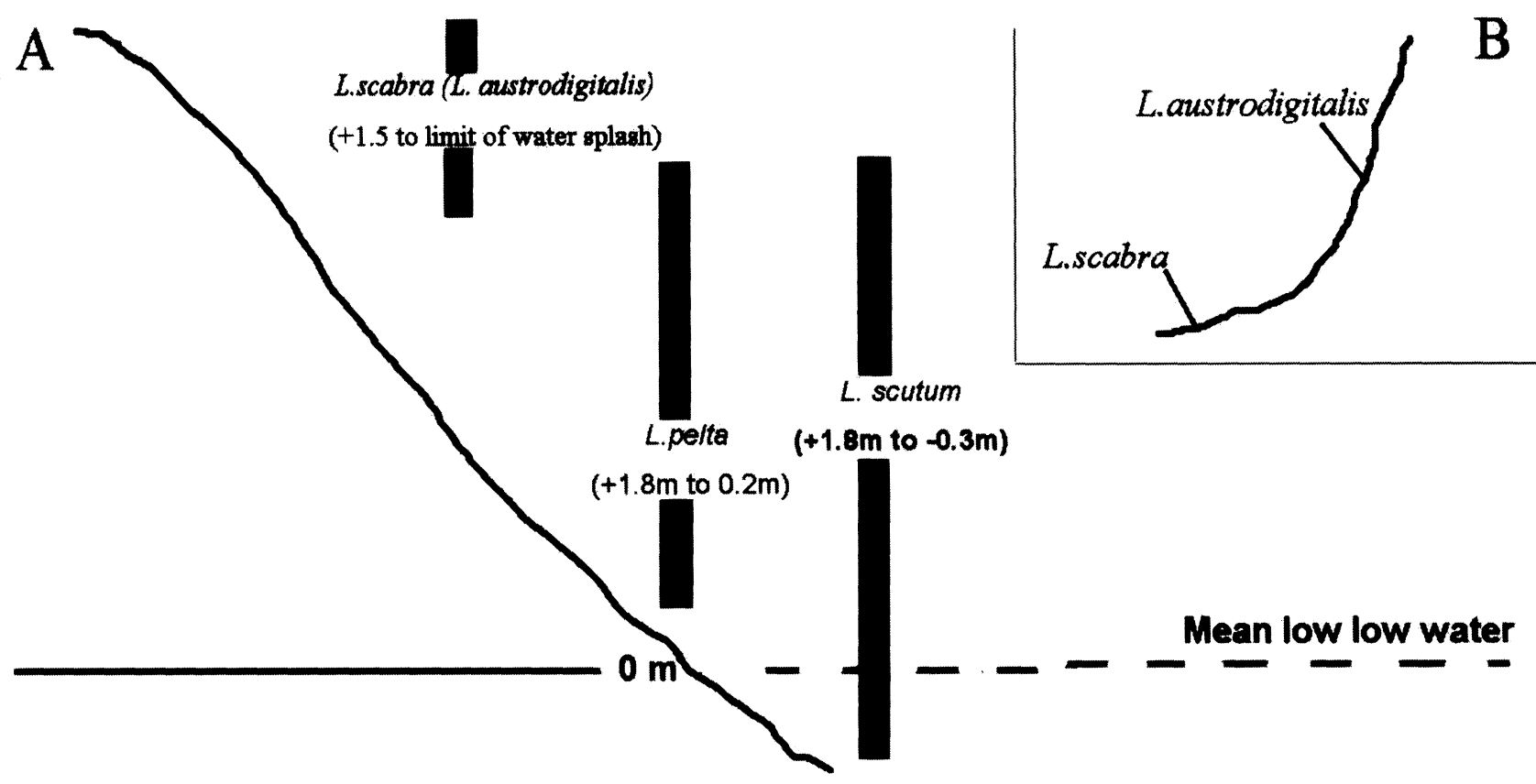

Figure 1. (A) Vertical distribution ranges of four Lottia species (L. scabra, L. austrodigitalis, L. pelta, and L. scutum); (B) $L$. scabra occupies primarily horizontal surfaces fully exposed to the sun, and $L$. austrodigitalis occupies primarily vertical or overhanging surfaces (after Shotwell, 1950; Haven, 1970; Wolcott, 1973).

\section{Heat shock}

Heat-shock treatments were carried out as described in Denny et al. (2006) (Fig. 2). The data from Denny et al. (2006) indicate that limpets at HMS may experience two general types of stressful temperature exposures in the field, which the authors termed "abrupt" and "gradual." In an abrupt exposure, limpet body temperatures rise to a maximum level, after which the limpet is rapidly immersed by the rising tide and body temperature quickly equalizes with ocean temperature. Alternatively, in a gradual exposure, body temperature rises to the maximum value and then falls slowly back toward ocean temperature through the remainder of the low tide period, resulting in a longer overall emersion. We recreated these two exposure regimes using a temperature-controlled wind tunnel chamber in which air temperature, substratum temperature, and relative humidity of the air could be controlled separately to simulate the physical conditions in the field. Limpets were taken from the holding tank during "high tide" and placed on the wetted substratum of the wind tunnel chamber with initial air and substratum temperatures of $14{ }^{\circ} \mathrm{C}$, a typical water temperature at HMS. The temperature of the substratum was increased to designated temperatures $\left(24,28,32\right.$, and $\left.36{ }^{\circ} \mathrm{C}\right)$ at a rate of $8^{\circ} \mathrm{C}$ per hour, a natural heating rate (Denny et al., 2006). In the "abrupt" exposure, the temperature, upon reaching the designated maximum, was held constant until a total time of $3.5 \mathrm{~h}$ had elapsed since the start of the exposure, after which the limpet was immediately returned to flowing seawater $\left(14{ }^{\circ} \mathrm{C}\right)$ to recover for $1 \mathrm{~h}$. In the "gradual" exposure, after achieving the target temperature, the temperature was held at the designated level for the allotted time, and then decreased to $14{ }^{\circ} \mathrm{C}$ at a rate of $8{ }^{\circ} \mathrm{C}$ per hour, for a total exposure time of $7 \mathrm{~h}$. Hereafter, we will refer to these two general exposure profiles in terms of the total duration of the aerial emersion, i.e., $3.5 \mathrm{~h}$ or $7 \mathrm{~h}$. During the experiments, the humidity was maintained at $50 \%-60 \%$, and air temperature tracked the substratum temperature up to a maximum of $30^{\circ} \mathrm{C}$ and then tracked substratum temperature back down to $14{ }^{\circ} \mathrm{C}$ during 7 -h exposures. The wind speed was held at a constant $0.25 \mathrm{~m}$ $\mathrm{s}^{-1}$ in all trials. After recovery in flowing seawater for $1 \mathrm{~h}$, the limpets were frozen at $-70{ }^{\circ} \mathrm{C}$ until being analyzed for Hsp70 expression. For each species except $L$. austrodigitalis $(n=20)$, five individuals were heated in each treatment. A larger sample of $L$. austrodigitalis was necessary because genetic identification could only be done after treatment. A non-heat-stressed group of five limpets from each species ( $n=20$ for $L$. austrodigitalis) was placed in the chamber and aerially exposed at $14{ }^{\circ} \mathrm{C}$ for $3.5 \mathrm{~h}$ or $7 \mathrm{~h}$, after which they were allowed to recover in seawater for $1 \mathrm{~h}$ and were then frozen.

\section{Preparation of foot muscle tissue samples}

About $50 \mathrm{mg}$ of foot muscle tissue was homogenized in $300 \mu \mathrm{l}$ of homogenization buffer $\left(32 \mathrm{mmol} \mathrm{l}^{-1}\right.$ Tris- $\mathrm{HCl}$, $\mathrm{pH} 6.8 ; 2 \%$ SDS). Protease inhibitors were added following the protocol of the manufacturer (Complete-Mini, Roche, Mannheim, Germany). The samples were incubated at 


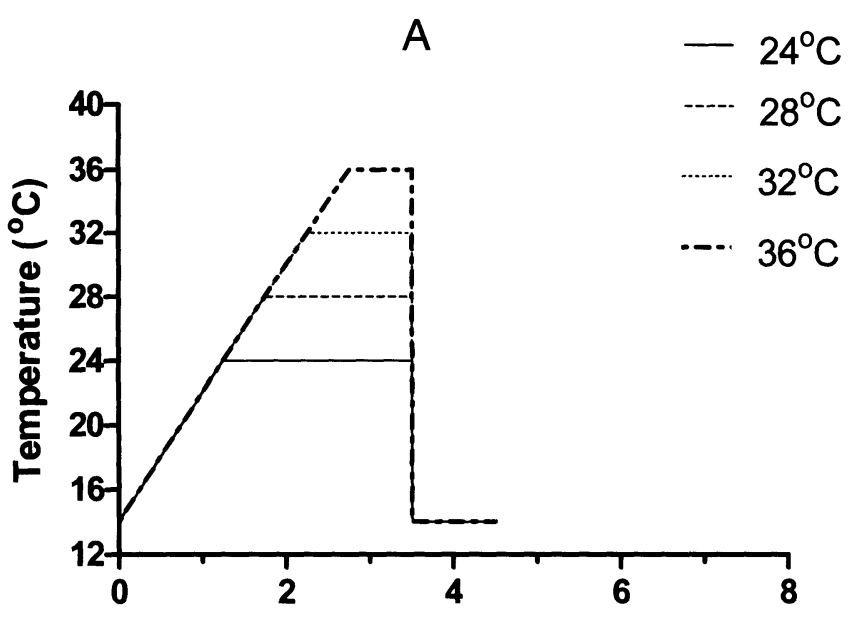

B

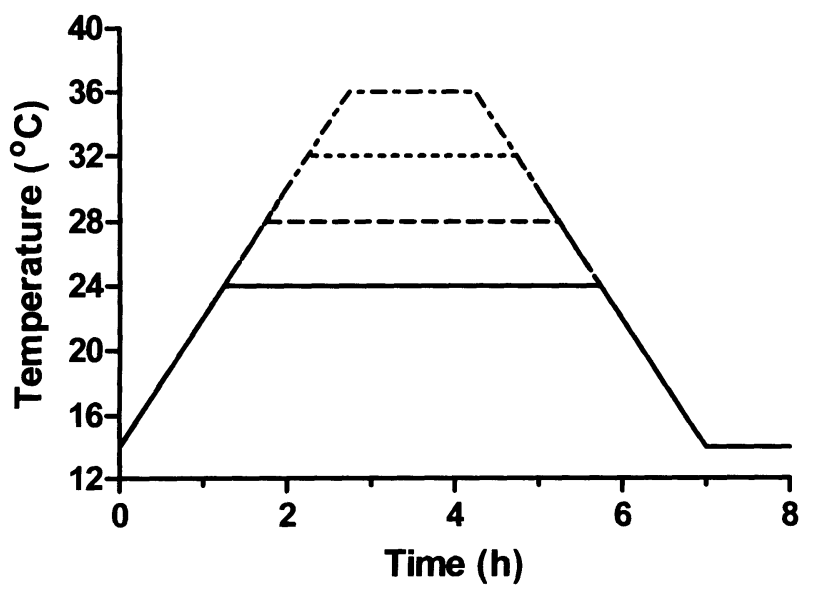

Figure 2. Diagram of the heat-shock protocol. Limpets were acclimated at $14{ }^{\circ} \mathrm{C}$ for at least 7 days. Five temperature regimes $\left(14^{\circ} \mathrm{C}, 24^{\circ} \mathrm{C}\right.$, $28^{\circ} \mathrm{C}, 32{ }^{\circ} \mathrm{C}$, and $36^{\circ} \mathrm{C}$ ) were designed. Temperature increased from 14 ${ }^{\circ} \mathrm{C}$ to the designated temperature at a rate of $8{ }^{\circ} \mathrm{C}$ per hour. After exposures of $3.5 \mathrm{~h}$ (A) and $7 \mathrm{~h}(\mathrm{~B}), 5$ specimens per treatment were sampled and returned to $14{ }^{\circ} \mathrm{C}$ seawater for $1 \mathrm{~h}$ of recovery.

$100{ }^{\circ} \mathrm{C}$ for $5 \mathrm{~min}$, and then homogenized for $2 \mathrm{~min}$ at a frequency of $25 \mathrm{~s}^{-1}$ using a Tissuelyser (Retsch GmbH, Haan, Germany). The homogenate was centrifuged at $20,000 \times g$ for $15 \mathrm{~min}$, and the supernatants were transferred to new tubes. Samples were stored at $-20^{\circ} \mathrm{C}$. Protein concentration of the samples was determined using the BCA protein assay reagent (Pierce, IL, USA).

\section{Western blotting for Hsp70}

After boiling at $100{ }^{\circ} \mathrm{C}$ for $5 \mathrm{~min}$, samples were mixed 1:1 (v/v) with Laemmli sample buffer (BioRad, CA, USA) plus 5\% 2-mercaptoethanol. Equal amounts of protein (7.5 $\mu \mathrm{g})$ were loaded in each lane and electrophoresed on $10 \%$ pre-cast Tris- $\mathrm{HCl}$ polyacrylamide gels (BioRad, CA, USA).
After electrophoresis, proteins were transferred onto nitrocellulose membranes (MSI Nitrobind, $0.45 \mu \mathrm{m}$ ) using a wet transfer. Transfer was carried out at $80 \mathrm{~V}$ for $2.5 \mathrm{~h}$ or $30 \mathrm{~V}$ overnight with a transfer buffer containing $25 \mathrm{mmol}^{-1}$ Tris-HCl, $193 \mathrm{mmol} \mathrm{l}^{-1}$ glycine, and $20 \%$ methanol. Following transfer, the membrane was blocked with $5 \%$ nonfat dried milk in Tris-buffered saline (TBS, $25 \mathrm{mmol}^{-1}$ Tris$\mathrm{HCl}$ and $150 \mathrm{mmol}^{-1} \mathrm{NaCl}$ ) for $2 \mathrm{~h}$, and then incubated for $1.5 \mathrm{~h}$ with the primary antibody solution of mouse antiHsp70 monoclonal antibody (MA3-008, Affinity Bioreagents, CO, USA) diluted 1:5000 in a solution containing $2.5 \%$ bovine serum albumin in TBS $/ 0.1 \%$ Tween. After being washed three times with TBS/ $0.1 \%$ Tween, the membrane was incubated for $1 \mathrm{~h}$ with the secondary antibody (SAB-100, StressGen Biotechnologies British Columbia, Victoria, Canada) diluted 1:10,000. After six more washes with TBS $/ 0.1 \%$ Tween, the western blot was developed using ECL detection (Amersham, Buckinghamshire, UK), and exposed to X-ray film (ISC BioExpress, UT, USA) for 5-10 s. The films were scanned and the bands were quantified using ImageJ ver. 1.38 (Abramoff et al., 2004). Samples were diluted to ensure that the band intensities fell within the linear range of the detection system.

A total of $30 \mathrm{ng}$ of human Hsp70 protein (NSP555, StressGen, Biotechnologies British Columbia, Victoria, Canada) was loaded in each gel and used as the standard for normalization within and among gels. Hsp70 levels in limpets were expressed as values relative to the level of this standard sample (relative unit, RU; \%).

\section{Statistics}

The data were analyzed using the SPSS 13.0 statistics package (Chicago, IL, USA). The assumption of homoscedasticity was tested with a Levene's test. To investigate interspecific differences in Hsp70 in the field and after acclimation (control), one-way ANOVA was performed. To investigate the effect of the different temperatures on Hsp70 expression of the individual species, one-way ANOVA was performed followed by Duncan post hoc pairwise comparisons. To investigate the inter-specific differences in Hsp70, two-way ANOVA was performed. Differences were considered significant if $P<0.05$.

\section{Results}

The antibody used in this study detected only a single band of Hsp70 in foot muscle of the four species of Lottia. The molecular weight of Hsp70 detected in limpets is similar to that of the recombinant human Hsp70 isoform. Because the sole Hsp70 we detected exhibited changes in expression following heat shock, we designate the isoform as an inducible one, even though it is expressed constitutively as well.

In the field samples, the Hsp70 level of $L$. scabra was 
Figure 3. Hsp70 levels in Lottia scabra, L. austrodigitalis, L. scutum, and L. pelta in field, control, and $14{ }^{\circ} \mathrm{C}$ treated samples. Control animals were acclimated for 14 days at $14{ }^{\circ} \mathrm{C}$. Values are mean $\pm 1 \mathrm{SE}(n=5)$. Letters indicate statistical significance between treatments within a species, based on Duncan post hoc comparisons $(P<0.05)$.

significantly higher than that of the other three species (Fig. $3)$. Hsp70 level of $L$. austrodigitalis was significantly higher than that of $L$. scutum and L. pelta $\left(F_{(3,19)}=30.426, P<\right.$ 0.001 , Duncan post hoc comparison), and there was no significant difference in Hsp70 between the two low-intertidal congeners.

After acclimation at $14{ }^{\circ} \mathrm{C}$ for 14 days ("control" samples), Hsp70 levels of all species showed a slight decline relative to the field samples, though this was significant only in $L$. scutum ( $P=0.028$, Student's $t$ test) (Fig. 3). The control samples for the two high-shore species, L. scabra and $L$. austrodigitalis, were not significantly different from each other, but Hsp70 levels of $L$. scabra and L. austrodigi- talis remained higher than those of $L$. scutum and L. pelta $\left(F_{(3,19)}=4.433, P=0.019\right)$, consistent with a higher level of constitutive (non-heat-induced) synthesis in the highintertidal congeners.

After heat shock, two-way ANOVA results showed significant differences among species in both exposure durations, as well as a significant effect of temperature in the 7-h exposures (Table 1). In the 3.5-h exposure, there was no significant difference in the levels of Hsp70 within a species across different exposure temperatures (Fig. 4A). However, levels of Hsp70 expression differed among species. The levels of Hsp70 in L. scabra and L. austrodigitalis were significantly higher than in $L$. scutum and L. pelta $\left(F_{(3,99)}=\right.$

Table 1

Two-way ANOVA on the effect of temperature on $\mathrm{Hsp} 70$ in the four Lottia species after exposure at $14{ }^{\circ} \mathrm{C}, 24^{\circ} \mathrm{C}, 28^{\circ} \mathrm{C}, 32{ }^{\circ} \mathrm{C}$, and $36{ }^{\circ} \mathrm{C}$ for $3.5 \mathrm{~h}$ or $7 \mathrm{~h}$

\begin{tabular}{|c|c|c|c|c|c|}
\hline Source & Type III Sum of Squares & df & Mean Square & $F$ & Sig. \\
\hline \multicolumn{6}{|c|}{ Hsp70 levels in 3.5 -h exposure } \\
\hline Species & 222785.957 & 3 & 74261.986 & 56.551 & $<0.001$ \\
\hline Temperature & 5634.062 & 4 & 1408.515 & 1.073 & 0.376 \\
\hline Species $\times$ temperature & 12058.871 & 12 & 1004.906 & 0.765 & 0.684 \\
\hline \multicolumn{6}{|l|}{ Hsp70 levels in 7-h exposure } \\
\hline Species & 9.768 & 3 & 3.256 & 20.768 & $<0.001$ \\
\hline Temperature & 4.475 & 4 & 1.119 & 7.136 & $<0.001$ \\
\hline Species $\times$ temperature & 3.779 & 12 & 0.315 & 2.009 & 0.034 \\
\hline
\end{tabular}




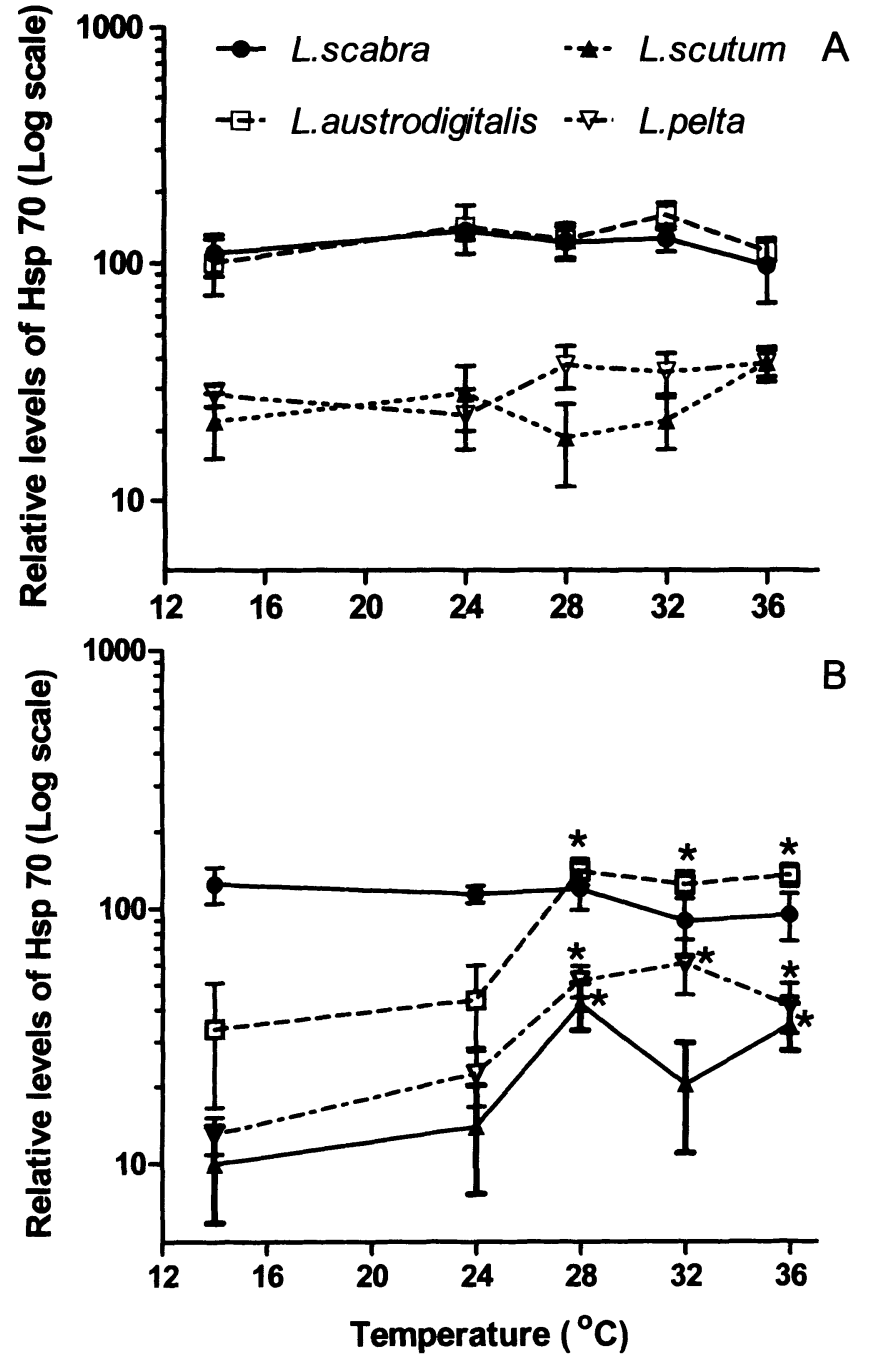

Figure 4. Hsp70 levels in Lottia scabra, L. austrodigitalis, L. scutum, and $L$. pelta after exposure to $14^{\circ} \mathrm{C}, 24^{\circ} \mathrm{C}, 28^{\circ} \mathrm{C}, 32{ }^{\circ} \mathrm{C}$, and $36^{\circ} \mathrm{C}$ for $3.5 \mathrm{~h}(\mathrm{~A})$ and $7 \mathrm{~h}(\mathrm{~B})$. Values are mean $\pm 1 \mathrm{SE}(n=5$ for data points except for the $L$. scutum samples at $28^{\circ} \mathrm{C}$ in the 7-h exposure, where $n=$ 4). An asterisk indicates the temperature at which $\mathrm{Hsp} 70$ is significantly higher than at a treatment temperature of $14{ }^{\circ} \mathrm{C}$ (Duncan post hoc comparison).

58.080, $P<0.001$, Duncan post hoc comparison). The $14^{\circ} \mathrm{C}$ treatment samples for $L$. austrodigitalis, $L$. pelta, and L. scutum all showed Hsp70 levels elevated over their acclimatized control samples, with the two low-shore species showing a significant increase $\left(F_{(3.19)}=3.722, P=\right.$ 0.033 , L. scutum $; F_{(3,19)}=12.885, P<0.001$, L. pelta, Duncan post hoc comparison) (Fig. 3).

In the 7-h exposure, the Hsp70 levels in L. scabra were similar to what was observed in the 3.5-h exposure (Fig. 4B), and there was no significant difference among exposure temperatures $\left(F_{(4,24)}=0.624, P=0.651\right.$, Duncan post hoc comparison). In the other three species, levels of Hsp70 increased with increasing exposure temperature, and the relative increase in expression also differed among species.
In L. austrodigitalis, post hoc comparisons showed that Hsp70 levels at temperatures of 28,32 , and $36{ }^{\circ} \mathrm{C}$ were significantly higher than at $14{ }^{\circ} \mathrm{C}$ and $24{ }^{\circ} \mathrm{C}\left(F_{(4,24)}=\right.$ 11.154, $P<0.001$, Duncan post hoc comparison). In $L$. scutum, relative levels of $\mathrm{Hsp} 70$ at $28^{\circ} \mathrm{C}$ and $36{ }^{\circ} \mathrm{C}$ were significantly higher than at $14{ }^{\circ} \mathrm{C}\left(F_{(4,24)}=3.375, P=\right.$ 0.030 , Duncan post hoc comparison). In L. pelta, Hsp70 levels at 28,32 , and $36{ }^{\circ} \mathrm{C}$ were significantly higher than at $14{ }^{\circ} \mathrm{C}\left(F_{(4,24)}=4.980, P=0.006\right.$, Duncan post hoc comparison), and the maximum Hsp70 levels occurred at $32{ }^{\circ} \mathrm{C}$.

\section{Discussion}

The four Lottia species in the present study occupy different heights in the intertidal zone and may also assume different orientations to the sun (Shotwell, 1950; Haven, 1970; Wolcott, 1973), leading to the possibility of diverse levels of thermal stress among the four congeners. Though both $L$. scabra and $L$. austrodigitalis are found in the high-intertidal zone, the fine-scale distributions of these two species are different. $L$. scabra primarily occupies horizontal surfaces fully exposed to the sun, whereas $L$. austrodigitalis typically occupies vertical or overhanging surfaces where exposure to solar radiation may be less than that encountered by individuals of $L$. scabra occurring at the same height (Denny et al., 2006). The two low-intertidal species, L. pelta and L. scutum, generally are not exposed for long periods during low tides and thus experience lower thermal stress than either of the two high-intertidal congeners. Our data suggest that the heat-shock responses of the species reflect these differences in thermal stress encountered in their normal habitats.

Numerous studies show that rocky intertidal animals' thermotolerance limits are related to their vertical zonation (Sanders et al., 1991; Tomanek and Somero, 1999; Stillman and Somero, 2000; Somero, 2002; Berger and Emlet, 2007). Wolcott (1973) used exposure methods similar to the ones used here to measure the lethal limits of some of the same species we tested, and found that high-intertidal species $(L$. scabra and $L$. digitalis) can tolerate higher temperatures compared to low- and mid-intertidal species ( $L$. pelta and $L$. scutum). L. austrodigitalis can tolerate higher temperatures than $L$. digitalis (Y. Dong, unpubl. data). The $\mathrm{LT}_{50}$ values for $L$. digitalis and $L$. austrodigitalis were $39.50-40.72{ }^{\circ} \mathrm{C}$ (95\% confidence limits) and $40.50-41.72{ }^{\circ} \mathrm{C}$, respectively.

Among the many types of adaptive physiological responses to thermal stress (Hochachka and Somero, 2002), the heat-shock response appears to play a pivotal and nearly ubiquitous role (Feder and Hofmann, 1999; Sørensen et al., 2003). Several studies have shown that the level of expression of heat-shock proteins is related to thermotolerance in a number of species occupying different tidal zones (Hofmann and Somero, 1996; Tomanek and Somero, 2000; 
Buckley et al., 2001; Tomanek and Sanford, 2003; Sorte and Hofmann, 2005). However, most studies have only examined inducible synthesis in conspecifics in response to different levels of acute heat stress; little attention has been paid to whether levels of constitutively produced Hsps differ among species in concert with the intensity of heat stress they experience in their habitats. We used solid-phase immunochemical (western) analysis to investigate this question.

The antibody used in the present study (MA3-008) can detect several members of the mammalian $h s p 70$ gene family, including Hsp70 and Hsc70. However, only one Hsp70 band was detected in congeners of Lottia. There are precedents for heat-induced increases in expression of Hsp70 paralogs that are normally expressed constitutively (Lindquist, 1986). Thus, the single isoform detected in congeners of Lottia may belong to a group of molecular chaperones that is expressed for normal "housekeeping" functions in protein biosynthesis yet is also up-regulated when needs for chaperone activity increase due to stress.

The Hsp70 expression responses of the four congeners differed in both field and laboratory-acclimated specimens. In the field, the high-intertidal species ( $L$. scabra and $L$. austrodigitalis) had higher constitutive levels of Hsp70 compared to the mid- and low-intertidal species ( L. scutum and $L$. pelta). These higher levels of expression in the higher-occurring species persisted after 14 days of acclimation to $14{ }^{\circ} \mathrm{C}$, suggesting that the high levels found in field specimens were not simply a consequence of recent heat stress. Previous studies showed that the half-life of Hsp70 is rather short-6-9 h in Drosophila (Landry et al., 1982), 2 days in Morris hepatoma 7777 cells (Lindquist, 1986). Therefore, the 14-day acclimation used in this study should have been long enough to allow for the decay of any Hsp70 produced in response to thermal stress encountered shortly before the specimens were collected. We interpret the higher levels of Hsp70 in L. scabra and L. austrodigitalis to indicate that a relatively high potential for thermal denaturation of proteins exists under field conditions and that these two species use a "preparatory defense" strategy to ensure that adequate levels of heat-shock proteins are available to cope with unpredictable but extreme periods of heat stress. This energetically costly strategy is not found in the two lower-occurring congeners.

Induction of Hsp70 during laboratory heat stress also differed among species. All species except $L$. scabra showed increased levels of Hsp70 when exposure temperature in the 7-h experiment reached $28^{\circ} \mathrm{C}$. L. austrodigitalis induced Hsp70 more strongly than the low-shore species ( $L$. scutum, L. pelta) did. The maximum Hsp70 expression in $L$. scutum and $L$. pelta occurred at $28{ }^{\circ} \mathrm{C}$ and $32{ }^{\circ} \mathrm{C}$, respectively. Levels of Hsp70 in L. austrodigitalis increased at $28{ }^{\circ} \mathrm{C}$, and kept stable at 32 and $36^{\circ} \mathrm{C}$. The Hsp70 level in L. austrodigitalis was higher than those of the two low- and mid-intertidal species ( $L$. scutum and L. pelta) at high temperatures. These results indicate that $L$. austrodigitalis can adapt to the harsh physical conditions in the high-intertidal area with a moderate level of constitutive Hsp70 and a high level of inducible Hsp70, and the low-intertidal species can express inducible $\mathrm{Hsp} 70$ in response to infrequent exposure to heat stress during extreme low tides. A difference in Hsp70 expression between high- and low-shore species has previously been demonstrated for mid- and low-shore species of snails of the genus Tegula (Tomanek and Somero, 1999), and reflects the separate evolutionary histories of these species.

The finding that Hsp70 levels in L. scabra did not change with the increasing exposure temperatures could be a consequence of the high levels of Hsp70 found normally in this species. Thus, according to the "molecular thermometer" model (Craig and Gross, 1991) for regulation of the heatshock response, high standing-stock levels of Hsp70 prohibit the activation of the $h s p 70$ gene. Likewise, the relatively low standing-stock levels of Hsp70 in L. pelta and $L$. scutum may account for the strong induction of Hsp70 synthesis at temperatures above $\approx 24{ }^{\circ} \mathrm{C}$ in the gradual 7 - $\mathrm{h}$ exposure.

In the 3.5 -h exposure, by contrast, there were no significant changes in Hsp70 levels among temperature treatments for any species. However, unlike in the 7-h exposure, low-shore limpet species ( $L$. scutum and $L$. pelta) exposed to the $14{ }^{\circ} \mathrm{C}$ treatment for $3.5 \mathrm{~h}$ showed Hsp70 levels significantly elevated over control acclimated animals (Fig. 3 ). These elevated levels among $14{ }^{\circ} \mathrm{C}$ treatment groups may obscure temperature-related changes in the other treatments. The cause of these elevated levels of Hsp70 in limpets not experiencing thermal stress cannot be explicitly determined by this experiment, but may be related to desiccation: limpets moved from control conditions $\left(14{ }^{\circ} \mathrm{C}\right.$ on the seawater table, where relative humidity was high and air movement was negligible) to the treatment chamber (50\%$60 \%$ relative humidity and wind velocities of $0.25 \mathrm{~m} \mathrm{~s}^{-1}$ ) would have experienced a sudden increase in desiccating conditions, possibly resulting in an initial spike in Hsp70 synthesis. It is possible that such a desiccation-induced increase in $\mathrm{Hsp} 70$ would provide protection against thermal stress later in the tidal cycle.

In conclusion, the congeneric limpets occupying different vertical positions in the intertidal zone and having different orientations to incoming solar radiation have different responses to heat stress. $L$. scabra, which occupies primarily horizontal surfaces fully exposed to the sun in the highintertidal zone, exhibits high constitutive levels of Hsp70, but no induced synthesis under the heat-stress conditions used in this study. L. austrodigitalis, which occupies primarily vertical or overhanging surfaces in the high-intertidal zone, has a moderate level of constitutive Hsp70 in the field and high inducible synthesis of Hsp70 at high temperature. 
The lower-occurring species ( $L$. scutum and $L$. pelta) maintain low levels of Hsp70, but highly induce synthesis when exposed to heat stress. Although the energy costs of synthesizing and utilizing Hsps as molecular chaperones have not been quantified in terms of their percentage contribution to cellular energy budgets, the higher levels of Hsp70 production in high-intertidal congeners of Lottia are likely to lead to a different balance of energy allocation between growth, reproduction, and maintenance than is found in less thermally stressed low- to mid-intertidal species.

\section{Acknowledgments}

We are grateful to Prof. Stephen Palumbi and Dr. Ryan Kelly for their help in genetic identification of $L$. digitalis and $L$. austrodigitalis. We are grateful for the helpful suggestions of two referees, especially the conjecture by one referee that exposure to desiccation stress might trigger Hsp70 synthesis that subsequently proves beneficial in coping with heat stress. This study was supported by National Science Foundation grant IOS-0718734, and by a fellowship from the China Scholarship Council to YD. This is contribution number 305 from PISCO, the Partnership for Interdisciplinary Studies of Coastal Oceans funded by the Gordon and Betty Moore Foundation and the David and Lucile Packard Foundation.

\section{Literature Cited}

Abramoff, M. D., P. J. Magelhaes, and S. J. Ram. 2004. Image processing with ImageJ. Biophotonics Int. 11: 36-42.

Berger, M., and R. B. Emlet. 2007. Heat-shock response of the upper intertidal barnacle Balanus glandula: thermal stress and acclimation. Biol. Bull. 212: 232-241.

Blanchette, C. A., B. S. T. Helmuth, and S. D. Gaines. 2007. Spatial patterns of growth in the mussel, Mytilus californianus, across a major oceanographic and biogeographic boundary at Point Conception, California, USA. J. Exp. Mar. Biol. Ecol. 340: 126-148.

Branch, G. M., and R. C. Newell. 1978. A comparative study of metabolic energy expenditure in the limpets Patella cochlear, $P$. oculus, and P. granularis. Mar. Biol. 49: 351-361.

Buckley, B. A., M. Owen, and G. E. Hofmann. 2001. Adjusting the thermostat: the threshold induction temperature for the heat-shock response in intertidal mussels (genus Mytilus) changes as a function of thermal history. J. Exp. Biol. 204: 3571- 3579.

Castenholz, R. W. 1961. Effect of grazing on marine littoral diatom populations. Ecology 42: 783-794.

Collins, L. S. 1977. Abundance, substrate, angle, and desiccation resistance in two sympatric species of limpets. Veliger 19: 199-203.

Craig, E. A., and C. A. Gross. 1991. Is hsp70 the cellular thermometer? Trends Biochem. Sci. 16: 135-140.

Crummett, L. T., and D. J. Eernisse. 2007. Genetic evidence for the cryptic species pair, Lottia digitalis and Lottia austrodigitalis and microhabitat partitioning in sympatry. Mar. Biol. 152: 1-13.

Davies, A. J., M. P. Johnson, and C. A. Maggs. 2007. Limpet grazing and loss of Ascophyllum nodosum canopies on decadal time scales. Mar. Ecol. Prog. Ser. 339: 131-147.

Dayton, P. K. 1971. Competition, disturbance, and community organization: the provision and subsequent utilization of space in a rocky intertidal community. Ecol. Monogr. 41: 351-389.
Denny, M. W., and C. D. G. Harley. 2006. Hot limpets: predicting body temperature in a conductance-mediated thermal system. J. Exp. Biol. 209: 2409-2419.

Denny, M. W., L. P. Miller, and C. D. G. Harley. 2006. Thermal stress on intertidal limpets: long-term hindcasts and lethal limits. J. Exp. Biol. 209: 2420-2431.

Feder, M. E., and G. E. Hofmann. 1999. Heat-shock proteins, molecular chaperones, and the stress response: evolutionary and ecological physiology. Annu. Rev. Physiol. 61: 243-82.

Haven, S. B. 1970. Niche differences in the intertidal limpets Acmaea scabra and A. digitalis (Gastropoda) in central California. Veliger 13: 231-248.

Helmuth, B. S. T. 2002. How do we measure the environment? Linking intertidal thermal physiology and ecology through biophysics. Integr. Comp. Biol. 42: 837-845.

Helmuth, B.S.T., N. Mieszkowska, P. Moore, and S. Hawkins. 2006. Living on the edge of two changing worlds: forecasting the responses of rocky intertidal ecosystems to climate changes. Annu. Rev. Ecol. Evol. Syst. 37: 373-404.

Hochachka, P. W., and G. N. Somero. 2002. Biochemical Adaptation: Mechanism and Process in Physiological Evolution. Oxford University Press, New York.

Hofmann, G. E., and G. N. Somero. 1996. Interspecific variation in thermal denaturation of proteins in the congeneric mussels Mytilus trossulus and $M$. galloprovincialis: evidence from the heat-shock response and protein ubiquitination. Mar. Biol. 126: 65-75.

Landry, J., D. Zbernier, P. Chretien, L. M. Nicole, R. M. Tanguay, and N. Marceau. 1982. Synthesis and degradation of heat shock proteins during development and decay of thermotolerance. Cancer Res. 42: 2457-2461.

Lindquist, S. 1986. The heat-shock response. Annu. Rev. Biochem. 55: 1151-1191.

Morimoto, R. I., and M. G. Santoro. 1998. Stress-inducible responses and heat shock proteins: new pharmacologic targets for cytoprotection. Nat. Biotechnol. 16: 833-838.

Murphy, P. C. G. 1978. Collisella austrodigitalis sp. nov: a sibling species of limpet (Acmaeidae) discovered by electrophoresis. Biol. Bull. 155: 193-206.

Nakano, T., and T. Ozawa. 2007. Worldwide phylogeography of limpets of the order Patellogastropoda: molecular, morphological and paleontological evidence. J. Molluscan Stud. 73: 79-99.

Palumbi, S. R. 1996. Nucleic acid. II. The polymerase chain reaction. Pp. 205-249 in Molecular Systematics, 2nd ed., D. M. Hillis, C. Moritz, and B. K. Mable, eds. Sinauer Associates, Sunderland, MA.

Roberts, D. A., G. E. Hofmann, and G. N. Somero. 1997. Heat-shock protein expression in Mytilus californianus: acclimatization (seasonal and tidal-height comparisons) and acclimation effects. Biol. Bull. 192: 309-320.

Roland, W., and R. A. Ring. 1977. Cold, freezing and desiccation tolerance of the limpet Acmaea digitalis (Eschscholtz). Cryobiology 14: $228-235$.

Sanders, B. M., C. Hope, V. M. Pascoe, and L. S. Martin. 1991. Characterization of stress protein response in two species of Collisella limpets with different temperature tolerances. Physiol. Zool. 64: 14711489.

Shotwell, J. 1950. Distribution of volume and relative linear measurement changes in Acmaea, the limpet. Ecology 31: 51-61.

Somero, G. N. 1995. Proteins and temperature. Annu. Rev. Physiol. 57: 43-68.

Somero, G. N. 2002. Thermal physiology and vertical zonation of intertidal animals: optima, limits, and costs of living. Integr. Comp. Biol. 42: 780-789.

Sørensen, J. G., T. N. Kristensen, and V. Loeschcke. 2003. The 
evolutionary and ecological role of heat shock proteins. Ecol. Lett. 6: 1025-1037.

Sorte, C. J. B., and G. E. Hofmann. 2005. Thermotolerance and heatshock protein expression in Northeastern Pacific Nucella with different biogeographical ranges. Mar. Biol. 146: 985-993.

Stillman, J. H., and G. N. Somero. 2000. A comparative analysis of the upper thermal tolerance limits of eastern Pacific porcelain crabs, genus Petrolisthes: influences of latitude, vertical zonation, acclimation, and phylogeny. Physiol. Biochem. Zool. 73: 200-208.

Tomanek, L., and B. Helmuth. 2002. Physiological ecology of rocky intertidal organisms: a synergy of concepts. Integr. Comp. Biol. 42: 771-775.

Tomanek, L. and E. Sanford. 2003. Heat-shock protein 70 (Hsp70) as a biochemical stress indicator: an experimental field test in two congeneric intertidal gastropods (genus: Tegula). Biol. Bull. 205: 276-284.

Tomanek, L. and G. N. Somero. 1999. Evolutionary and acclimation- induced variation in the heat-shock responses of congeneric marine snails (Genus Tegula) from different thermal habitats: implications for limits of thermotolerance and biogeography. J. Exp. Biol. 202: 29252936.

Tomanek, L., and G. N. Somero. 2000. Time course and magnitude of synthesis of heat-shock proteins in congeneric marine snails (genus Tegula) from different tidal heights. Physiol. Biochem. Zool. 73: 249256.

Tomanek, L., and G. N. Somero. 2002. The roles of heat-shock proteins 70 (hsp70) and 90 (hsp90) and the heat-shock transcription factor-1 (HSF-1) in regulating the stress response in congeneric marine snails (genus Tegula) from different thermal habitats. J. Exp. Biol.205: 677685

Wolcott, T. G. 1973. Physiological ecology and intertidal zonation in limpets (Acmaea): a critical look at "limiting factors." Biol. Bull. 145: 389-422. 